\title{
Low perceived risk: A challenge to adoption of preventive behaviors for COVID-19?
}

Population Council Institute

Follow this and additional works at: https://knowledgecommons.popcouncil.org/departments_sbsr-pgy

Part of the Demography, Population, and Ecology Commons, International Public Health Commons, and the Public Health Education and Promotion Commons How does access to this work benefit you? Let us know!

\section{Recommended Citation}

Population Council Institute. 2020. "Low perceived risk: A challenge to adoption of preventive behaviors for COVID-19?" brief. New Dehli: Population Council Institute. 
